\title{
Örgüt Kültüründe Bir İş Ahlakı Problemi Olarak Nepotizm
}

\author{
Nepotism as a Work Ethic Problem in Organization Culture
}

\section{Sonay AKAR}

Doktorant, Giresun Üniversitesi, SBE, Issletme A.B.D., tsonay61@gmail.com

https://orcid.org/0000-0002-7707-3465
Makale Başvuru Tarihi: 02.03.2020

Makale Kabul Tarihi: 11.05.2020

Makale Türü: Araştırma Makalesi $\begin{aligned} & \text { Anahtar } \\ & \text { Kelimeler: }\end{aligned}$
Nepotizm,
Örgüt,
İs Ahlakl,

Nepotism,

Organization,

Work Ethic,
Nepotizm, örgüt içinde yönetsel açıdan ișe alma ve işe yerleștirmede akrabalık ilişkileri ve yakınlık derecesinin göz önüne alındiğı bir kavramdır. Kayırmacılık türlerinden biri olan bu anlayış örgüt amaçları için sıklıkla uygulanmaktadır. Bu noktadan hareketle çalışmanın amacı nepotizmin örgütün lehine mi yoksa aleyhine mi olduğunu ortaya koymaktır. Bu amaçla örgütlerdeki bu yaygın anlayışın iş ahlakı bağlamında değerlendirilmesinin daha doğru olacă̆ı kanısına varılmıştır. Çünkü örgütlerdeki nepotizm uygulaması ile birlikte işgörenler liyakat durumlarına bakılmadan üst düzey işlerde görev alabilmekte, kayırılmayan diğer işgörenler ise bu durumdan olumsuz bir şekilde etkilenmektedir. Bu çalı̧̧ma örgütlerde karşılaşılan nepotizm ve uygulamaları, iş ahlakı bakış açısıyla çalışanların terfide kayırmacılık, işe alma sürecinde kayırmacılık ve işlem kayırmacılı̆̆ faktörleri altında incelenmiştir. Araştırmada nepotizme etki eden pek çok faktöre bağlı olarak ortaya çıkan nepotizm örneklerinin yarattığı etkiler açısından incelenerek bir durum analizi yapılmıştır.

\begin{abstract}
Nepotism is a concept that takes into degree of closeness and the relationship in hiring and job placement managerially within the organization. This concept which is one of the types of nepotism, is often applied for organizational purposes. The purpose of working from this point, of the nepotism is to reveal that there is in favor of or against of the organization. For this purpose,, it was concluded that it would be more correct to evaluate in the context of work ethic of this common understanding in organizations. Because employees can take part in high level jobs without regard of their merit status with the implementation of nepotism in organizations, if other employees who are'nt favored are affected adversely from this situation. This study has been examined under the factors transaction nepotism, nepotism in the recruitment process and nepotism in promote of employees with business ethic perspective of practices and nepotism encountered in organizations. In the research, a situation analysis was made by examining its in terms created effects of nepotism samples that emerged by depending many factors affecting nepotism.
\end{abstract}




\section{GIRISS}

Dünya genelinde yaşanan ekonomik daralma artan nüfusa karşılık işgücü piyasasında sürekli artan işsizliğe sebebiyet vermektedir. Örgütsel açıdan bakıldığında rekabet, kurumsal yönetim sorunları düşük performans gösteren örgütlerin yok olmasıyla sonuçlanmaktadır (Bellow, 2003). Ancak aynı zamanda rekabet avantajı bir örgüt için önemli sayılmaktadır. Bu da nitelikli bir işgücü, insan sermayesi aracılığıyla sağlanabilmektedir (Ombando, 2018:474).

21. yüzyılda modern işletmelerde örgüte dair sadece örgüt kültürünün oluşması yeterli gelmemekte aynı zamanda örgütte çalışanlarında örgüte ait kültürü benimsemesi ve buna uygun davranış ve tutum göstermesi gerekmektedir. Bu yüzden çalışanların işyerlerindeki örgüt kültürünü nasıl algıladıklarını anlayabilmek için, hem kültürün içselleştirilmesi hem de örgütün çalışma alanında başarıyı yakalayabilmesi adına örgütün içinde gelişen nepotizm ve iş ahlakı anlayışları açısından incelemek zorunlu hale gelmiştir.

Örgüt kavramı tanım itibariyle insanların belirli amaçlarını yerine getirmek için oluşturdukları düzenlemeler şeklinde ifade edilebilir (Robbins ve Coulter, 2007:60). Örgütler topluluklardan meydana gelmektedir. Bir topluluğun ortaya çıkmasında etkin olan kültür kavramının da örgütle olan ilişkisi önemli kabul edilmektedir. Çünkü örgütteki kültür örgütün kişiliğini göstermektedir (Naktiyok, 2001).Örgüt kültürü işgörenleri bir amaç etrafında toplayan ve onların tutum ve davranışlarını etkileyen değer, norm, inanç varsayım ve sembollerden oluşan bir sistemi içermektedir (Özkan ve Gümüş, 2013:1).

Örgüt kültürü literatürde tanımı ve türleri itibariyle çok değişik şekilllerde ifade edilmektedir. Ancak genel ifade ediliş tarzına bakıldığında güçlü ve zayıf kültürler şeklinde bir ayrım yapıldığı görülmüştür. Örgüt kültüründe kültürü iyi yada kötü, güçlü ya da zayıf olarak nitelendirmek ahlaki açıdan uygun düşmese de güçlü bir örgüt zayıf örgüte göre başarıyı yakalamada daha etkinse tercih edilen örgüt kültürü güçlü örgütü kültürü olacağ 1 gözükmektedir (İşcan ve Timuroğlu, 2007:122). Literatürde örgüt kültürü bu konuyu inceleyen araştırmacıların adıyla anılmakta, farklı biçimlerde modelleştirilmeye ve sınıflandırmaya tabi tutulmaktadır. Bu kültür çeşitlerinin de kendi içinde boyutları yer almaktadır. Laurent'in politik, otorite, rol formulasyon, hiyerarşik; Trompeenaar'ın genel, özel, bireyselllik, ortaklaşa, zaman, kesinlik belirsizlik; Quinn ve Cameron'ın klan, adokrasi, hiyerarşi, piyasa; Harrison ve Handy’nin güç, rol, görev, kişi kültür ayrımları başlıcalarıdır.

İş dünyasında iş ahlakı vicdani bir görev bakış açısıyla paydaşlarına etiksel bağlamda adaletli olmaları gerektiğini gösteren bir kavramdır. Fakat değişen dünya düzeninde 21. Yüzyılda ortaya farklı amaçlar ve kar güdüsüyle iş ahlakı kavramı ihlal edilmektedir. Ortaya çıkan usulsüzlükler ve suistimaller bu kavramı destekler niteliktedir (Dana ve Dienhart, 2007:163).

İş ahlakının meslek hayatında başarı için kabul edilen yeni faktörlerden değildir. Bir protestan ahlakının bir iş ahlakı biçimi ekonomik perspektiften önemli olduğu kabul edilmiştir. Diğerleri ise iş ahlakının önemini ve işyerinde refah ile olan ilgisini belirlemiştir. Örneğin, bir çalışanın iş ahlakı kişinin kendine güvenini etkileyebilir. Düşük bir özgüven, düşük iş tatmini ve düşük iş performansı ile sonuçlanan motivasyonun azalmasına neden olabilir. Buna bağlı çalışmalar, güçlü bir iş ahlakı ve işçi verimliliği arasında pozitif bir bağlantı olduğunu göstermiştir (Cao ve Bill, 2019:10).

Nepotizm günümüzde Dünya çapında ve Türkiye'de giderek artan bir uygulama olarak örgütlerde karşımıza çıkmaktadır. İşgücünün nitelikleri ve yetenekleri dikkate alınmadan tamamen yöneticilerin sosyal olarak bağlı oldukları kişilerin lehine yapılan bir kayırmacılık türüdür (Alesina ve Giuliano, 2007:1). Nepotizmde kayırmacılığın yapılmasını sağlayan sebep kan bağı (akrabalık) iken, diğer kayırmacılık türlerinde eş, dost, arkadaş, siyasi yakınlık, partizanlık, hemşerilik gibi sebepler etkilidir.

21. yüzyılın rekabetçi iş piyasasında işverenler, sadece teknik yeterliliğe sahip değil, aynı zamanda güçlü iş ahlakı özellikleri sergileyen çalışanlar aramaktadırlar. İşverenler, iş ahlakının global olarak rekabetçi bir piyasada rekabet avantajı sağladığının farkındadır, çünkü üretkenliği arttırmaktadır. Sağlam bir iş ahlakına sahip çalışanlar, her zaman çaba göstermeye istekli olurken, sıkı çalışarak kişisel mükemmellik, memnuniyet ve başarı elde etmek istemektedirler (Coa ve Bill, 2019:11).

$\mathrm{Bu}$ çalışmada birinci bölümde Türk ve Yabancı literatürdeki örgütlerdeki iş ahlakına ve nepotizme ilişkin çalışmaları incelenmiştir. Daha sonra Nepotizm kavramının tarihi, sebepleri, türleri, olumlu, olumsuz etkileri ve son olarak da Dünya'da ve Türkiye'de yapılmış olan Nepotizm örnekleri anlatılmıştır. 


\section{LITERATÜR}

Literatürde Nepotizm ve kayırmacılık bakımından örgütteki işgörenlerin ve ya entelektüel sermaye bileşenlerinin organizasyon içerisindeki nepotizm uygulamaları, işgörenlerin işletmeye olan bağlılıklarını azalttığı sonucunu çıkarılmıştır. Bu sonuca bağlı olarak örgütün faaliyetlerdeki başarısını ve daha mikro düzeyde bireylerin ekonomik refahını negatif biçimde etkilemektedir.

Merrens ve Garrett (1975) güçlü bir Protestan ahlakına sahip işçilerin daha fazla zaman harcadıklarını ve ürettiklerini ortaya koymuşlardır. Araştırmaları, iş ahlakının görev için harcanan zamandaki etkisi için nispeten büyük bir etki büyüklüğü ortaya çıkarmıştır. Greenberg (1977) iş ahlakının görev üzerinde 1lımlı ve kalıcı bir etkisi olduğunu bulmuştur. Kan (1969), iş ahlakı ve iş tatmini arasında ortalama 0.17 korelasyon olduğunu bildirmiştir. Kanıtlar, bu sosyal normla ilgili öngörülerin ve artan anlayışın işyerinde verimlilik ve rekabetçiliğin artmasıyla ilgili olduğunu açıkça göstermektedir.

Büte (2011), Türkiye'de ki kamu bankalarına yapılan anketler sonucunda, 243 işgörenden alınan değerlendirmelerde nepotizm ve kayırmacılığa yönelik uygulamaların insan kaynaklarındaki işlevselliğe ve uzmanlaşmaya zarar verdiğini, örgütteki bağlılıkta önemli bir faktör olan iş tatminini ve iş ahlakını düşürdügünü tespit etmiştir. Düz (2010) yaptığı araştırmasında, işyerlerindeki personelin nepotizm bilincinin, görev yaptıkları kurumsal yap1 üzerine olan etkisini incelenmiş ve personelin nepotizm bilinci, görevde yükselmede kayırmacılık, işe alma aşamasında kayırmacılık ve işlem kayırmacılığı olmak üzere üç farklı boyutta değerlendirilmiştir. $\mathrm{Bu}$ araştırmanın neticesinde, işgörenlerin nepotizm algısının örgütsel bağlılık algısıyla birleştiğinde iş ahlakına olumsuz yönde etki ettiği ortaya koyulmuştur.

Karahan ve Yılmaz (2014), sağlık sektöründeki işgörenlere yönelik yapılan anket çalışmasında 272 işgörenin zihinlerindeki nepotizm algısının üyesi oldukları örgüte bağlılıklarına olan etkisini araştırmıştır. Bu çalışmadaki araştırmacılar işgörenlerin nepotizm algısını terfide kayırmacılık, işe alma sürecinde kayırmacılık ve işlem kayırmacılığı olmak üzere üç kapsamda incelerken, işgörenlerin örgüte olan bağl1lıklarını da duygusal bağlılık, devam bağlılığı ve normatif bağlılık olmak üzere üç farklı açıdan incelemişlerdir. Sonuç olarak bu çalışma nepotizmin işgörenlerin örgütsel bağl1lıklarını düşürdüğünü bulmuştur. Çalışmada, nepotizmin, işgörenler üzerindeki olumsuz etkisinin dışında, işletmelere ve topluma da olumsuz etkilerinin de olabileceği konusu üzerine önemle gidilmiştir.

Özkanan ve Erdem (2015), Türkiye'de devlet kuruluşlarından olan dört değişik bakanlıktaki tecrübeli 26 işgörenden alınan bilgiler dahilinde, bu kurumlarda terfideki kayırmacılık uygulamalarının daha fazla olduğunu buna karşın nepotizm ve hemşericilik uygulamalarında düşüşlerin olduğu belirlenmiştir. Bu çalışmada çıkarılan genel sonuç itibariyle siyasi kayırmacılığın en fazla kullanılan kayırmacılık çeşidi olduğu ortaya koyulmuştur.

Erusta ve Akdeniz (2016) nepotizme dair yaptıkları araştırmada, nepotizmin gelişmişlik düzeyi farklı olan ülkelerde kullanılanılan bir uygulama olduğu belirtmişlerdir. Çalışmada bu uygulamanın yaygınlığının sebepleri de belirtilmiştir. Toplumda yaşayan bireyler, aralarında kan bağı olan kişilerin maddi ve manevi açıdan iyi olmaları istenilmektedir. Türk adet, örfleri ve müslümanlığın getirdiği başta aile bireylerinin gerçekliğiyle ortaya çıkan baskılar, doğu kültüründe aileye yakınlığından oluşan gerçeklik yapıları, gelişen ve az gelişmiş ülkelerdeki yüksek olan eksik istihdamın insanların nepotizme başvurmasına, gelişmişlik düzeyi düşük ülkelerde nitelikli çalışana ihtiyaç duyulmayan iş kollarının çokluğu sebebiyle işgören tercihinde ilk olarak güvenebileceği bireyleri seçmeleri, gelişen ülkelerdeki profesyonelliğin değerinin bilinilmemesidir.

\section{NEPOTIZM}

Nepotizmin kavramsal tanımında farklı bakış açılarının dikkate alınması önemli ve gereklidir. Bu açıdan bakıldığında insanlar neden nepotizme ihtiyaç duymaktadır sorusunun cevabını ve bu davranıs biçimini göstermenin altındaki sebebin ne olduğunu nepotizmin tarihine bakıldığında görmek mümkündür. Nepotizmin kavramsal çerçevesi, tarihi süreçte geçmiş, bugün ve gelecek analizi, nepotizmin uygulanmasının altında yatan sebepler ve türleri, nepotizmin avantajları ve dezavantajları, nepotizme karşı yapılabilecekler, ulusal ve uluslar arası mecradaki nepotizm uygulamaları incelenmiştir. 


\subsection{Nepotizmin Tarihi ve Kavramsal Çerçevesi}

Nepotizm, bireylerin beceri, yetenek, başarı ve eğitim düzeyi gibi liyakata bağlı olarak belirlenen özellikleri göz önüne alınmadan, yalnızca akrabalık dereceleri dikkate alınarak kişilerin istihdam edilmesi olarak açıklanmaktadır. Nepotizmin, kullanıldığında haksızlıklar ortaya çıkaran ve yaygın olarak örgütsel bağlantıları olumsuz etkileyen sonuçlar doğurmaktadır (Büte, 2011b:175).

Nepotizm, kamuya ait örgütlerde ve işletmelerde sıklıkla görülen sorunlardan biridir (Bayhan, 2002:1-13). Nepotizm kavramı genellikle olumsuz bir olayı ifade eder nitelikte kullanılmaktadır (Hayajenh vd., 1994:60-62; Aközer, 2003:14-22). Nepotizm kavramının Latince "Nepot" sözcügünden geldiği ve bunun İngilizce karşılığının Nephew (yeğen) olduğu 1985 ve 1998 yıllarında Abdalla ve Ford Mc Laughin tarafindan tespit edilmiştir (Asunakutlu ve Avc1, 2010:4). Nepotizm sözcüğünün büyük olumsuz algısının sebebi ve kökü Rönesans döneminde bazı Papa'ların, özelliklerinin dikkate alınmadan yeğenleri için üst seviye işler bulmaya yönelik hareketlerine dayanmaktadır. Bu uygulamanın o dönemlerde kilisenin etkinliği ve yeğen olmayan kişilerin moralleri üzerindeki olumsuz etki yüzünden kavramın olumsuz algılanmasında etkili olduğu kabul edilmektedir (Ciulla, 2005:155).

Adam kayırmacılık yirminci yüzyılda, siyasi patronaj deyimiyle akrabalar arasında bir mücadele haline geldiği ve nepotizm karşıtı politikalar ve sosyal amaçlar uygulanmaya konduğu görülmektedir (Bellow, 2003:1). Geçmiş dönemdeki yaşanan bu problemin, bugün ki analizinde çalışanların örgüte bağl1lıkları konusunda yaşanan bazı problemlerle açık şekilde benzerlikler gösterdiği düşünülebilir.

Türk Dil Kurumu, Nepotizmi "akraba ve yakın arkadaşları kayırma" biçiminde ifade etmektedir (http://www.tdk.gov.tr). Literatürde kayırmacılık adı altında nepotizmin yani akraba kayırmacılığına ilişkin pek çok tanım yer almaktadır; Bir kişinin yetenek, başarı ve eğitim seviyesi vb. özellikleri dikkate alınmadan yalnızca siyasetçi, bürokrat ve diğer kamu görevlileri ile olan yakın akrabalık ilişkileri göze alınarak bir devlet işinde istihdam edilmesine ve ya atanmasına akraba kayırmacılığ kayırmacılığı, reaktif bağların ve ilişkilerin yoğun olarak yaşandığı az gelişmiş ülkelerde daha fazla ortaya çıkmaktadır (Özsemerci, $2003: 20$ ).

Liyakatin gerektirdiği bir takım faktörleri göz önüne alınmadan gerekli niteliklere sahip olmayan bireylerin yalnızca kan bağı ilişkilerine bakılarak istihdam edilmesine ya da terfi edilmesine nepotizm denilmektedir. "Kin selection" veya akraba kayırma insanlarda (bazı biyologlara göre hayvanlarda da) var olan doğal bir içgüdüdür. Sosyal bilimlerde yer alan biyolojik/ekolojik bakış açılarında ise, nepotizmin rasyonel davranışlar sınıfına girdiğini söylemektedir. Bu bakış açılarında nepotizm, çevresel koşullar ve bireysel ihtiyaçlar alanı olarak tanımlanan sosyal ekolojide, "seçilmiş" bir davranış olarak belirtilmektedir (Özler vd., 2007:438).

Nepotizm,en sade şekliyle bir işletmede ya da örgütte akrabaların istihdamına olanak tanıyan bir kavram olarak tanımlanmaktadır (Karacaoğlu ve Yörük, 2012:46). Ayrımcılık ve kayırmacılık türlerinden olan, akraba kayırmacılığı olarak tanınan Nepotizm'de kayırmaya sebep olan varlık "kan bağ" iken, yakın bağlar gereği daha çok duygusallık etkin faktördür. Favorizm'de, aile dışındaki diğer yakın arkadaş, dost ve ahbap ile olan ilişkilerin ve baskıların gizli etkisinden söz edilebilir (Büte, 2011:388).

\section{NEPOTIZM UYGULAMASININ SEBEPLERİ VE TÜRLERİ}

Nepotizm olgusu kurumlarda işe alımdan başlayarak terfi etmeye, işgörenlere ait bütün uygulamalarda özellikle bir akrabanın atanması veya terfi etmesi ve bu sonuç itibariyle liyakat kurallarının göz ardı edilip, yakınlıkların türüne ve ilişkilerine bakılarak subjektif işlemlerin yapıldığı ve özellikle aile işletmelerinde kullanılmakta olan bir yöntemdir (Çivilidağ ve Şekercioğlu, 2016:6).

Aile işletmeleri açısından aileden gelen kişilerin avantajlı konumu itibariyle örgütteki üst düzey yöneticilerin aileden atanması, önemli bir strateji olarak sayılmaktadır. Bu stratejiler şu şekilde sıralanabilir (Karacaoğlu ve Yörük, 2012:48);

- Örgütte aile üyelerinin iktidar kaybını engellemesine yardım etmesi,

- Aile şirketlerinin sermayelerinin büyük kısmını kendi özkaynaklarından sağlama düşüncesi,

- İşi daha kısa öğrenme süresi,

- Daha düşük zarar, daha yüksek başarı, daha az işgücü devri, 
- Nepotizmin varlığı ile kurallara gerek duyulmadan daha kolay iletişimin sağlanacağı ve başarının sürekliliğini gerçekleştireceği,

- Aile üyesi olan işgücünün örgüte bağl1lığına olumlu etkileri olacağı kabul edilen bu stratejiler arasındadır.

Nepotizmin varolmasına sebep olan bütün bu stratejiler aile işletmelerinde çok fazla olmakla birlikte, kamu ve özel sektörde yoğun bir biçimde artarak devam etmektedir. Günümüzde iş yaşamında başarıdan ziyade çalışanlara olan güven duygusu nepotizm adı altında kendini göstermekte ve önemli sayılmaktadır.

\subsection{Nepotizmin Türleri}

Kavramsal analiz bağlamında çıkarılan sonuçta liyakatın varolmadığı bir ortamda kayırmacılığın ve nepotizmin (akraba kayırmacılı̆̆ı) yapıldığg görülmektedir. Bu yüzden bu aşamada nepotizmin türlerini inceleme faydalı olacaktır. Nepotizmin türleri konusunda literatüre bakıldığında yapılan araştırmalarda farklı anlayışların olduğu görülmektedir.

Nepotizmin türlerine geçmeden önce kayırmacılık (favoritism) ve Nepotizm (nepotism) Türkçe'de bu iki kavram arasında anlam birliği olmasına rağmen kayırmacılık daha kapsamlı anlama sahiptir ve önce bunlardan bahsetmenin konunun anlaşılması açısından faydalı olacağı öngörülmüştür. Şekil 1'de görüldüğü üzere kayırmacılığın türleri, özel ya da kamu iş alanında bir akrabanın atanması veya terfi etmesi akraba kayırma (nepotizm), kamu ya da özel iş alanında ekonomik işlerle ilgili durumlarda tanıdıklara öncelik verme eş, dost kayırma kronizm (croniysm), etnik, hemşerilik, dini ve politik taraftarlık himaye, patronaj (patronage), kamu kaynaklarını iktidar partisinin taraftar seçmenleriyle paylaşmaya klientelizm (clientelism) ve politik süreçte diğer bir yozlaşma biçimi ise yine iktidar partisince kamu kaynaklarının belirli bir seçim bölgesinde seçim kazanmak için seçmenlere dağıtılması partizanlık ya da hizmet kayırmacılığı (pork barreling) olarak adlandırılmaktadır. Nepotizmle, kronizm aslında birbirine yakındır, aralarındaki fark kronizmde kayrılan kişi akraba olmayıp, eş dost ya da arkadaş gibi ifade edilebilir (Özler ve Büyükarslan, 2011:278-279).

Devlet veya özel sektör yönetimindeki sistemlerde karşılaşılan bu davranış şekilleri bireylerin sistem içindeki görevlere atanmasında ya da terfi ettirilmesinde arkadaşlık, akrabalık, eş dost ilişkileri, partizanlık faktörlerinin hakim olduğu görülmektedir (Uz, 2011:72).

Şekil 1. Kayırmacılık ve Türleri

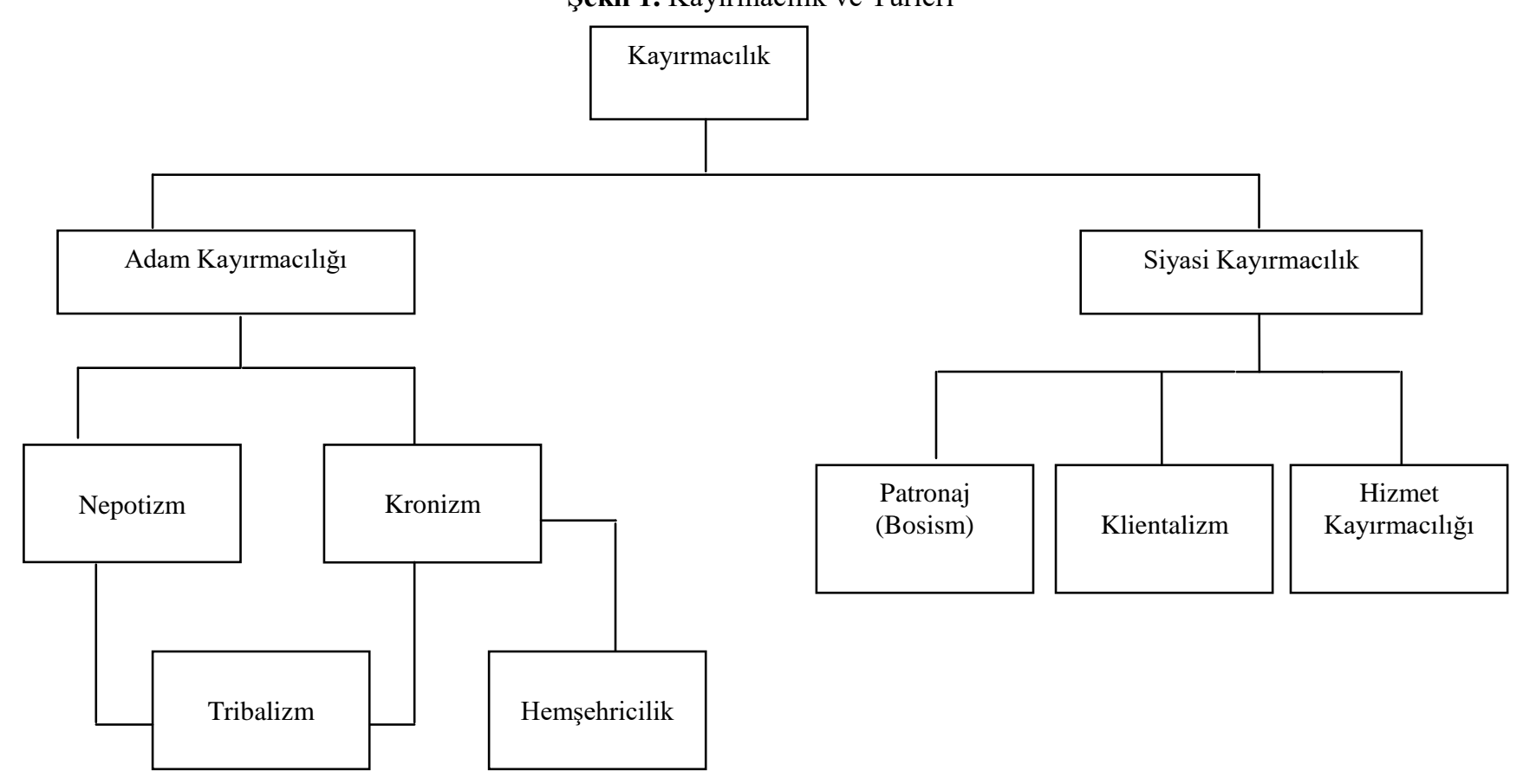

Kaynak: Özkanan ve Erdem, 2015:7.

Esas itibariyle nepotizmin türlerine bakıldığında; Vanhanen, etnik kayırmacılığı, büyük akraba toplulukları seviyesinde incelemekte ve kabul etmektedir. 1964 yılında Hamilton'un bulduğu etnik kayırmacılık Van den Berghe tanımlamasında sosyo biyolojik bir kuram olarak söz etmektedir. 
Jones koşullu, bireysel ve grup kayırmacıllktan söz etmiştir, koşullu nepotizmi "bir seçenek, sosyal olarak dayatılan karşılıklı zorlama, karşılıklı mutabık içeren kayırmacılık" olarak tanımlamışıı. Bireysel kayırmacılıkta akrabalık seviyesinde kardeş ve yarı kardeş şeklindeki bireyler arasında ayrım kayırmacılıkta da farklı fedakarlıklarla sonuçlanacaktır. Bu tanımlama bireysel kayırmacılıkta etkin olmaktadır. Grup kayırmacılığın gerçekleştiği zamanlarda ise, özveri yalnızca akrabalıkla ilgili olmayıp, ek olarak ortak kayırmacılık kuralını zorlamak için akraba grubunun beceri ve eğilimlerine de bağlı bulunmaktadır. Fakat grup kayırmacılıkta akrabalık derecesinin yakın akraba, uzak akraba şeklinde ayrım yapılması önemli etkilere sebebiyet vermektedir.

Bellow, nepotizmi daha genel ifadeyle kayırmacılığı eski ve yeni olarak nitelendirmiştir. Eski kayırmacılıkta, şirketin geleceği ve çıkarları göz önünde tutularak ailelerin kız ve erkek çocuklarını evlendirmesi bu kayırmacılık türünde yapılmaktadır. Yeni kayırmacılık ise, işletmenin yönetim sisteminde yukarıdan aşağıya doğru olmaktan çok aşağıdan yukarı doğru çalışmaktadır, zoraki bir durum değil istekler dahilinde sistem işlemektedir. Çünkü bu kayırmacılık türünde ailelerin etkinliği zoraki bir biçimde değil kendiliğinden devre dışı kalarak çocukların etkinliği önplanda olması sebebiyle ilişkilerde doğal olarak gelişmektedir (Bellow, 2003:3). Crocombe, kayırmacılığı adam kayırmacılığı türünde inceleyerek, bu kayırmacılıkta akrabalık ilişkileri ve saygınlığı olan birey için aşağıdan adam kayırma şeklinde gerçekleştiğini belirtmiştir.

Nepotizm açıklamalarda görüldüğü üzere farklı bakış açıları altında ve farklı türlerde incelendiği görülmüştür. Ancak ölçek bazında Ford ve Mc Laughin tarafından 1985 yılında geliştirilmiş, Hayajenh vd. tarafindan ise 1998'de ve daha sonra Asunakutlu ve Avcı tarafından 2010 yılında yapılan bir çalışmada kullanılan ölçeğe göre ise İşe Alma Sürecinde Kayırmacılık, İşlem Kayırmacılığı ve Terfi Sürecinde Kayırmacılık olmak üzere üç türde ele alınmıştır.

- Işse Alma Sürecinde Kayırmacılık; Bu kayırmacılık türüne işe alım sınavları örnek olarak gösterilebilinir. Liyakat durumlarına bakılmadan yakın akrabalıktan dolayı ortaya çıkan bir süreçtir.

- İşlem Kayırmacılı̆̆ ; aynı işyerinde çalışanların kayırmacılıktan dolayı bu çalışanların bir kısmının işin niteliğine göre daha avantajlı işlerde çalıştırılmasıdır. Yani çalışanların yeterlilikleri aynı fakat işin zorluğu vb özellikleri nedeniyle bir kısım kişilerin kayırılmasıdır. İşlem kayırmacılığını örgütsel adalet kavramı gerekliliklerinin yerine getirilmediği bir durum olarak da nitelendirebiliriz. Bu bağlamda bu araştırmada bağlantı kurulan örgütsel bağlılık üzerinde de çalışanların örgüte bağlılıkları konusunda olumsuz etki yapacağını apaçık göstermektedir.

- Terfi Sürecinde Kayırmacılık, terfi konusuna kavramsal olarak bakıldığında yüksek ücret, statü ve geniş yetkilerin bütününden oluşmaktadır. Örgütte başarılı, kendini kanıtlamış, özverili, liderlik özelliği olan sorumluluk alabilen kişilere sağlanan haktır. İşe alma kayırmacılığında kayırılmayanların örgütle ilgisi yoktur ve işlem kayırmacılığında da maddi bir gelir farkı yoktur. Ama terfi sürecinde kayırmacılıkta örgüt içi bir durum vardır ve beraberinde terfi ettirilmeyenlerin örgüte olumsuz etkilerinin (çatışmalar, işten ayrılmalar) göz önünde bulundurulması gerekmektedir (Çalık ve Naktiyok, 2018:345).

\section{NEPOTIZMIN ETKILERI}

\subsection{Olumlu Etkileri}

Nepotizme kavramsal ve tanımsal açıdan bakıldığında ortaya çıkan olumsuz düşüncelere karşın, Bellow (2003), "Nepotizme Övgü" isimli kitabında nepotizmi işletmelerin başarılı olmasında önemli bir faktör olarak kabul etmiştir. Nepotizmin farklı ve bir çok alanda uygulandığını ve kurumsallaşmış bir yapıya dönüştüğünü söylemektedir. Fakat bu çalışmada, işgörenler tarafından değil, işletmenin sürekliliği açısından bakılmıştır (Asunakutlu ve Avc1, 2009:731). Nepotizm ile birlikte genç kuşakların çalışmayan ve iş sahibi olmayan bireyler olarak aile sisteminin dışına çıkarılması önlenmektedir (Asunakutlu ve Avcı: 2010:97).

\subsection{Olumsuz Etkileri}

Nepotizmin örgütlerde işgörenler arasındaki ilişkilerini olumsuz etkilediği güvensizliğe ve doyumsuzluğa sebep olduğu, işgörenlerin işe karşı bağl11ıklarının azalttığı, çalışanlarda endişeyi artırdığı, adalet dışı uygulamalar yüzünden örgütsel bağl1lıkları azalttığı, ödül ya da işlerin görevlendirilmesinde performans yerine kişiler arası ilişkisinin iyi olduğu çalışanlara verildiği gibi negatif etkiler oluşmaktadır (Pearce, 2015:43). 
İşletmeler içinde kuvvetli akrabalık ve arkadaşlık bağların yaratılması işletmenin çıkarlarını olumsuz bir biçimde etkiler ve dışa kapalı bir örgüt yapısının oluşmasına sebep olur (Büte, 2011a:389).

Kayırmacılıkta kan bağı faktörüne bağlı olarak yapılan uygulamalar örgütlerde aile çatışmalarına, kuşaklararası savaşlara, bireylerin örgüte olan bağlılı̆ğnın zayıflamasına etkin ve nitelikli yöneticilerin örgütten uzaklaşmasına sebep olmaktadır. Özellikle aile şirketlerinde aile üyelerinin iktidar kaybını engellemeye yönelik bir strateji olarak benimsenen nepotizm, aslında profesyonel davranışın, örgüt içi demokratik yönetim biçiminin ve firmanın kurumsallaşmasının önünü tıkamaktadır (Özler vd., 2007:438-439).

Aslında Türkiye açısından düşünüldüğünde nepotizmin güncel ve en olumsuz etkisi beyin göçüdür (insan sermayesi kaçışı). Örneğin bu yılın başında Türkiye İşveren Sendikaları tarafından yapılan araştırmada, beyin göçünün Türkiye'nin gelişmesini negatif yönde etkilediğini belirtmiştir. Bu araştırmaya göre, Türkiye en fazla beyin göçü veren 34 ülke içinde 24. sırada yer alıyor. Türkiye, iyi eğitim alan her 100 kişiden 59'unu kaybederken, ülkede üniversitede okuyan gençlerin yüzde 73'ü yurtdışında çalışmak ve yaşamak istemektedir. $\mathrm{Bu}$ araştırmaya göre beyin göçünün Türkiye ekonomisine yıllık maliyeti 2.5 milyar doları bulduğu ifade edilmektedir. Almanya merkezli İstihdam Araştırma Enstitüsü Beyin Göçü Veritabanı'nın (IAB) verilerine göre ise Ekonomik Kalkınma ve İşbirliği Örgütü'ne (OECD) üye 20 ülke arasında yaşayan, yüksek okul ve üzeri eğitim seviyesine sahip Türkiyeli göçmenler, 30 yılda üç katına çıkmıştır. 1980'de yüzde 4.4 olan oran, 2010'da 12.4'e yükselmiştir (Kaya ve Çetin, 2008:23).

Türkiye İstatistik Kurumu'nun (TÜIK) göç istatistikleri şekil 2'de gösterilmektedir. Göç istatistikleri beyin göçünün Türkiye'deki durumunu ortaya koymaktadır. Açıklanan verilere göre ekonomik, siyasi, sosyal, kültürel nedenlerle Türkiye'den göç edenlerin sayısı 2017 yılında bir önceki yıla göre yüzde 42.5 artarak 253 bin 640 kişi oldu. Tüik rakamlarına göre, Türkiye'den göç eden nüfusun yaş grupları arasındaki dağılımına bakıldığında; en fazla göç edenler yüzde 15.5 ile 25-29 yaş grubudur. Bunu yüzde 14.4 ile 20-24 yaş ve yüzde 12.3 ile 30-34 yaş grubu izlemektedir (Tüik, http://tuik.gov.tr/PreHaberBultenleri.do?id=30607=).

Şekil 2. Türkiye’ye Gelen ve Türkiye'den Giden Göçün Cinsiyete Göre Dağılımı (2016 - 2017)

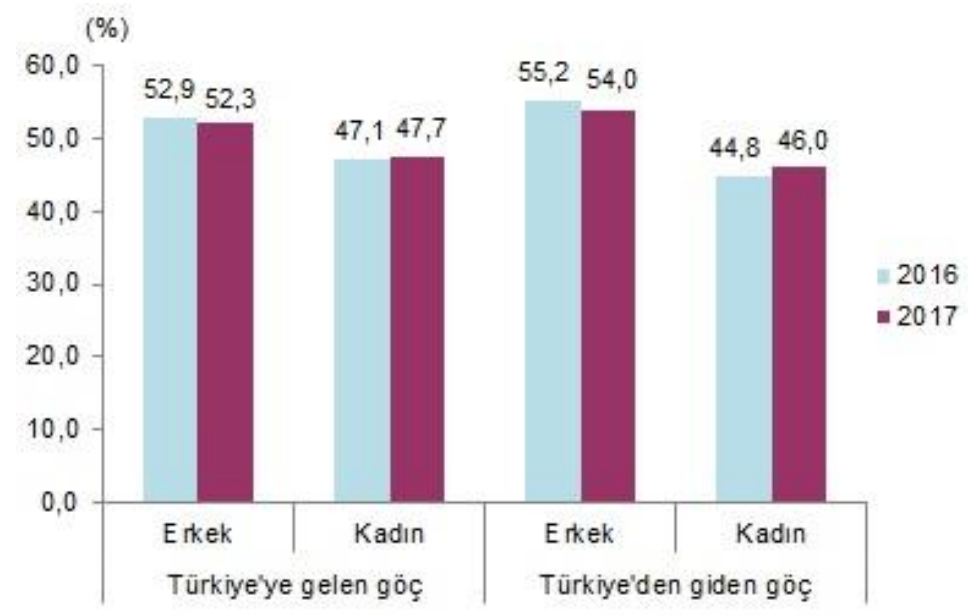

Kaynak: Tüik, 2019.

Smyrnios (2004) kayırmacılık uygulamalarının örgütlerde insan kaynakları departmanının özgür çalışmasının önünde engel olacağını, bunun da örgütlerin etkin nitelikli yöneticilerin oluşmasına engel olacağını belirtmiştir (Araslı vd., 2006:296). Brown (2003), örgütsel bağlılık konusundaki çalışmasında, kayırmacılıkçılığın örgütlenme içindeki dört temel olumsuz etkisini tanımladı (Ombanda, 2018:479);

- Çalışanların moral bozukluğu: Çalışanların daha az motive olmasıyla sonuçlanır.

- Dahili sabotaj: Diğer çalışanlar, niteliklerini ve amaçlarını sürekli olarak sorguladıkları için, tercih edilen çalışana kasten zarar vermeye çalışabilirler.

- Örgütteki güvensizlik: Çalışanların örgütten ayr1lmasıyla birlikte, örgütteki güven ve uyum yok olmaktadir. 
- Yüksek personel devir hızı: Nepotizmle ilişkisi olan çalışanlar terfi dişında tutulmakta fakat işverenin yakınlığı sayesinde yüksek ücret ödemesi yapılabilmektedir. Bu bir maliyet unsuru olarak örgütlerde ortaya çıkmaktadır.

Barney'in (1998) yaptığı çalışmalar, çalışanın olumsuz etkilerini göstermektedir. Kayırmacılık çok fazladır ve potansiyel olarak birkaç faktörün kombinasyonunu içermektedir. Düşük Kişisel Hesap Verebilirlik, Düşük Çalışan Hesap Verebilirliği, Düşük Verimlilik, Çalışan Moralsizliği, Düşük Güven İlişkisi, Düşük Müşteri Deneyimi ve Yüksek Performanslı Ciro (Ombando, 2018:480).

\section{TÜRKIYYE'DE VE DÜNYADA NEPOTIZM ÖRNEKLERİ}

Nepotizm örneklerine bakıldığında AB'de mecliste kuvvetler arasında yasama ve yürütme organındaki birlik içinde siyasi krize yol açan anlaşmazlığın sebebi yolsuzluklardı. Jacques Santer başkanlığındaki AB Komisyonu, Mart 1999'da görevinden toplu olarak istifa etti. Komisyonun eğitim ve araştırma mevzularından sorumlu Edith Cresson'un özellikle personel politikalarında yolsuzluklara (nepotizme) bulaşmış olmasından dolayı parlamento aracılığıyla istifası istenmiş, ancak kendisi görevi bırakmak istemeyince komisyonun tüm üyeleri istifa etmiştir (Demir, 2014:19).

Siyasi alanda gerçekleşmiş nepotizm örneğinden yola çıkılarak nepotizm yapıldığı takdirde sonuçlarının da ağır olacağı uygulanan yaptırımdan görülmektedir. Özellikle siyasi alanda yaygın olarak gerçekleştirilen nepotizmin olumsuz etkisinin olumlu etkisinden daha fazla olduğu apaçık görülmektedir.

Demokratik siyasette "hanedanlar" kayırmacılık önerebilmektedir. Hindistan'daki Ghandi ailesi veya ABD'deki Kennedy ve Bush aileleri, siyasi pozisyonlara yükseldiği ailelerin ünlü örnekleridir. Bu nepotizm türünde işe alımda ve terfi ettirilmede ekonomik ve siyasi gücün kullanıldığı görülmektedir (Sundell, 2013:6). İlhan ve Erdem, 2003 yılında gazetede yer alan bir nepotizm örneğini dikkate alarak farklı isim ve bilgilerle simülatif olarak açıkladığı örnekte aile üyelerinin ve eş dostunun kan bağı olan kişilerin örgütte istihdam ettiği ya da eş dostunun akrabalarını örgüt içinde terfi ettirildiği ortaya çıkarılmıştır (Erdem ve İlhan, 2010:135).

Nepotizm toplumda çeşitli şekillerde karşımıza çıkmaktadır. Kamu ve özel sektörde, siyasi alanda, akrabalar arasında ve sektör farkı gözetilmeden daha bir çok yerde nepotist davranışlar yapılmaya devam edilmektedir. Nepotizm bir davranış biçimi olmasının yanında yöneticilerin de kullandığı bir anlayıştır. Nitekim yöneticiler işletmeye olumlu etkileri olduğunu düşündükleri için nepotizmi savunmaktadırlar. Bunların sebepleri arasında tanıdıkların daha güvenilir olduğuna inanma, özellikle aile işletmelerinde iktidar değişikliğini engelleme, yakın akrabaların işe alımı ile işsizliği önleme gösterilmektedir.

Aile işletmelerinde yapılan nepotizmin olumlu sayılan etkilerinin yanında bir takım olumsuzlara da sebep olacağı bilinen bir gerçekliktir. Aile işletmelerinde iktidar kaybını engellemeye yönelik yaşanan anlaşmazlıklar işletmenin sürekliliğini olumsuz etkileyen önemli faktörlerdendir. Kayırmacılığın bir biçimi olan nepotizm ya da akraba, adam kayırmacılığı ekonomik açıdan az gelişmiş ya da gelişmekte olan ülkelerde daha fazla uygulanmaktadır. Aile işletmelerinde ortaya çıkan nepotizm ise daha çok gelişmiş ülkelerde kendini göstermektedir.

Nepotizme dair Almanya'da yapılan bir skandalda, birçok devlet temsilcisinin uzun zamandır eş ve çocuk asistanı olarak çalıştığı ortaya çıkmıştır. ABD'de, George W. Bush yönetimi, başkan yardımcısı Cheney ve yüksek mahkeme hakimi Antonio Scalia gibi etkili kişilerin çocuklarına bürokraside iş vermekle suçlanmıştır. İngiliz Avam Kamarası'ndaki parlamento üyelerinin eşleri rutin olarak sekreter olarak çalışmıştır. Literatürde örneklerin fazla olmasıyla birlikte nepotizmi sistematik olarak daha geniş bir ölçekte incelemek, liyakat yerine bağlantılar temelinde ne zaman işe alınacağının nasıl belirleneceği sorusu nedeniyle zordur (Sundell, 2013:5). Nepotizm örneklerinin etkilerini de içine alan nepotizm modeli, kavramsal açıklamalar çerçevesinde şekil 3'de gösterilmiştir: 
Şekil 3. Nepotizm Modeli

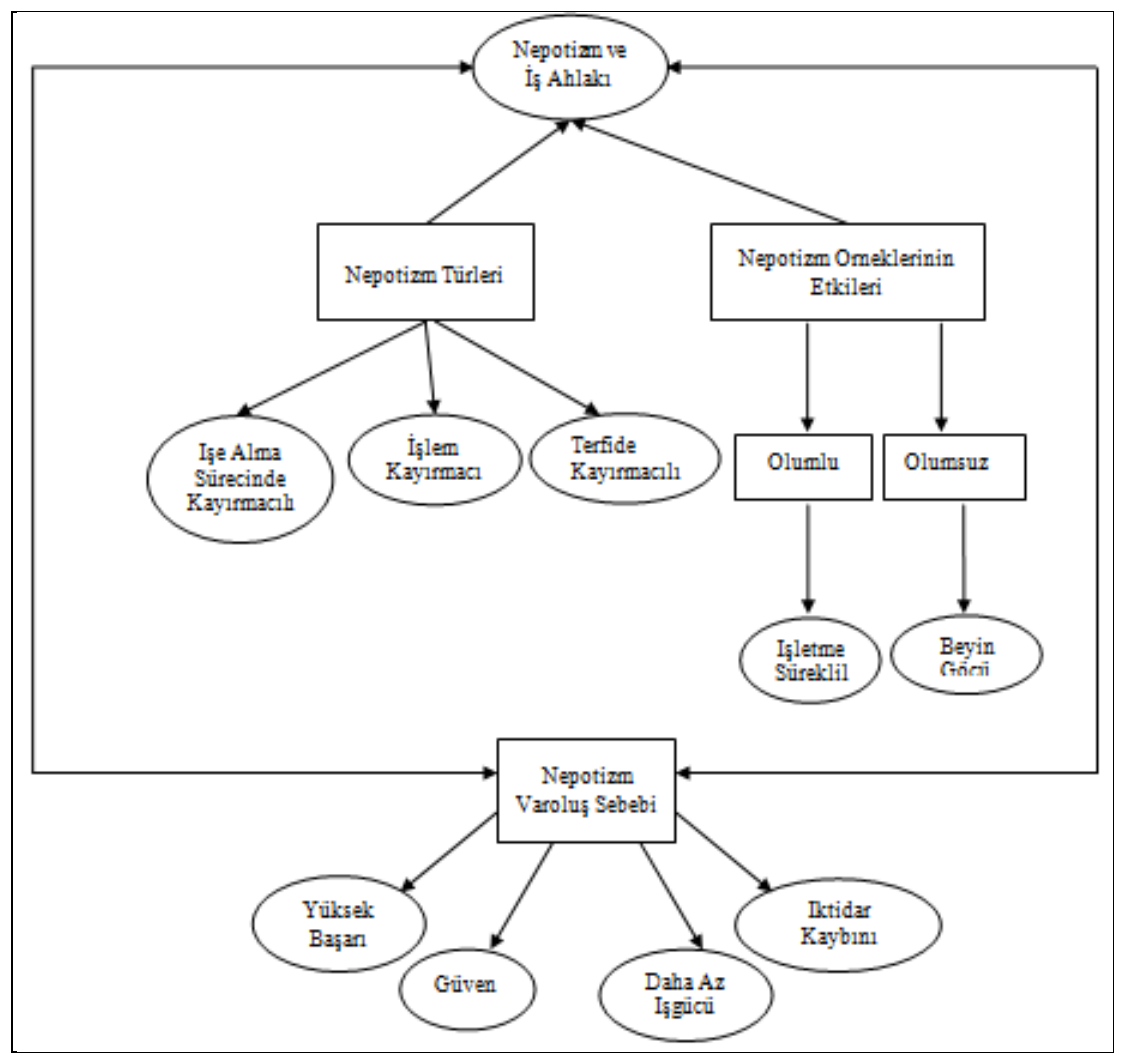

Kaynak: Şekil yazar tarafindan oluşturulmuştur.

\section{SONUC}

Yeni dünya düzeninde sürekli bir değişim içinde olan teknolojik ve ekonomik faktörler örgütün başarı düzeylerini etkilemektedir. Örgütler bu faktörlerin etkisi altında değişime ve rekabete ayak uydurmaya çalışmaktadır. Örgütlerin mekanik sistemler olmasının dışında aynı zamanda sosyal bir sistem açısından bakıldığında, örgütteki insan kaynağının özellikle sanayi devriminden sonra bu başarı ya da başarısızlıkta önemli etkisinin olduğu görülmüştür.

Bir örgütte işgörenlerin ya da entelektüel sermayenin işyerindeki nepotizm yaptırımları bireyler ve toplum üzerinde olumsuz etkilerinin ortaya çıktığı sonucuna varılmıştır. Çünkü örgüt içinde sadece örgüt kültürünün oluşması yeterli gelmemekte aynı zamanda örgütte çalışanlarında örgüte ait kültürü benimsemesi ve buna uygun davranış ve tutum göstermesi gerekmektedir. İşyerinde kayırmacılığın bir türevi olan nepotizmin varlığı önce bireyi olumsuz etkilenmekte daha sonra da örgütün ekonomik anlamda başarısızlığına etki etmektedir.

Genel olarak bakıldığında kayırmacılık ve bağlamındaki nepotizm olumsuz bir durum olarak nitelendirilmektedir. Aslında bireyleri bu davranış şekline iten sebepler ve doğurduğu sonuçlara bakıldığında bazı kesimler için nepotizmin olumlu olarak algılanmakta olduğu fark edilmiştir. İşsizlik, aile işletmelerinde güven duygusunun ön planda olması, işletmelerin sürekliliğinin düşünülmesi gibi sebepler nepotizm algısını olumlu olarak varsaymaktadır.

Aslında nepotizmin iyi ya da kötü bir davranış şekli olduğunu anlamada en doğru yöntem topluma olan etkisini dikkate almaktan geçmektedir. Bu bağlamda örgütlerdeki nepotizmin yapılan çalışmalar ve değerlendirmeler kapsamında pek çok faktörlerle bağ kurarak incelenmesi sonucunda literatürde olmayan ancak günümüz Türkiye'sinde nepotizmin ortaya çıkardığı en olumsuz etkinin ülke ekonomisine yarattığı maliyet açısından beyin göçü olduğunun tespiti yapılmıştır. Nitekim Tüik'in 2018 yılında yayınladığı istatistikte siyasi, ekonomik ve kültürel nedenler yüzünden göç edenlerin sayısındaki artış bu durumu destekler niteliktedir. 


\section{KAYNAKÇA}

AKÖZER, Mehmet (2003), “Катиоуи Gözüyle Kamuda Yolsuzluk”, Görüş Dergisi, S.12, ss.14-23.

ALESINA, Alberto ve GIULIANO, Paola (2007), "The Power of the Family", NBER Working Paper, National Bureau of Economic Research, Cambridge, ss.1-52, https://www.nber.org/papers/w13051.pdf (Erişim Tarihi: 03.01.2019).

ARASLI, Hüseyin, BAVIK, Ali ve EKİZ, Erdoğan H. (2006), "The Effects of Nepotism on Human Resource Management: The Case of Three, Four and Five Star Hotels In Northern Cyprus", International Journal of Sociology and Social Policy, S.26(7/8), ss.295-308.

ASUNAKUTLU, Tuncer ve AVCI, Umut (2010), "Aile İşletmelerinde Nepotizm Alglsı ve İş Tatmini İlişkisi Üzerine Bir Araştırma”, Süleyman Demirel Üniversitesi İktisadi ve İdari Bilimler Fakültesi Dergisi, S.15(2), ss.93-109.

BAYHAN, Vehbi (2002), "Demokrasi ve Sivil Toplum Örgütlerinin Engelleri: Patronaj ve Nepotizm", Cumhuriyet Üniversitesi Sosyal Bilimler Dergisi, S.26(1), ss.1-13.

BELlOW, Adam (2003), "In Praise of Nepotism", The Atlantic, http://www.theatlantic.com/magazine/archive/2003/07/in-praise-ofnepotism/302753/ (Erişim Tarihi: 30.04.2019).

BÜTE, Mustafa (2011a), "Kayırmacılı̆̆ın Çalışanlar Üzerine Etkileri ile İnsan Kaynakları Uygulamaları Ilişkisi: Türk Kamu Bankalarına Yönelik Bir Araştırma", Atatürk Üniversitesi Sosyal Bilimler Enstitüsü Dergisi, S.15(1), ss.383-404.

BÜTE, Mustafa (2011b), “Nepotizmin Iș Stresi Iș Tatmini Olumsuz Söz Söyleme ve Ișsten Ayrllma Niyeti Üzerine Etkileri: Aile İşletmeleri Üzerinde Bir Araştırma”, Çukurova Üniversitesi Sosyal Bilimler Enstitüsü Dergisi, S.20(1), ss.175-194.

CİULLA, Joanne (2005), “In Praise of Nepotism?”, Business Ethics Quarterly, S.15(1), ss.153-160.

ÇALIK, Abdurrahman ve NAKTIROK, Atilhan (2018), "Nepotizmin Örgütsel Sessizliğe Etkisinde Öz Yeterlilik Algısının Rolü: Hastane Çalışanları Üzerine Bir Araştırma”, Ege Akademik Bakış, S.18(3), ss.343-351.

ÇIVİLIDAĞ, Aydın ve ŞEKERCiOĞLU, Güçlü (2016), "İşe Personel Alma Nepotizm ve Örgütsel Gelişme Hakkında İnsan Kaynakları Çalışanlarının Görüşlerine İlişkin Nitel Bir Analiz”, 4. Örgütsel Davranış Kongresi Bildiriler Kitabı, 4-5 Kasım 2016, Çukurova Üniversitesi Yayını, Adana, ss.102-125.

DANA L, Gold ve DIENHART, John W. (2007), "Business Ethics in The Corporate Governance Era: Domestic And International Trende-s in Transparency, Regulation, And Corporate Governance", Business And Society Review, S.112(2), ss.163-164.

DEMIR, Fatih (2014), “Кати Yönetiminde Etik: Tartışma ve Birkaç Örnek”, İnsan \& İnsan Dergisi, S.1, ss.14-22.

ERDEM, Ramazan (2010), “Akraba Kayırmacılı̆̆ (Nepotizm)”, Yönetim ve Örgüt Açısından Kayırmacılık (Der. Ramazan Erdem), Beta Yayınları, İstanbul, ss.135-166.

ERUSTA, Murat ve AKDENIZ, Murat (2016), “Çalı̧̧ma Hayatında Nepotizm ve Liyakat”, E-Doküman, ss.128, https://docs.google.com/document/d/1uOKkFJ_MP5uwelHmDoLkhJ5CsRs5oGShUceuP_W9n-g/edit (Erişim Tarihi: 02.05.2019).

FORD, Robert ve MCLAUGHIN, Frank (1985), “Nepotism”[Nepotizm], Personnel Journal, S.64(9), ss.57-61.

HAYAJENH, Abdalla F., MAGHRABI, Ahmed S. ve AL-DABBAGH, Taher H. (1994), "Research Note: Assessing the Effect of Nepotism on Human Resource Managers", International Journal of Manpower, S.15(1), ss.60-67.

İşCAN, Ö. Faruk ve TIMMUROĞLU, M. Kürşat (2007), “Örgüt Kültürünün İş Tatmini Üzerindeki Etkisi ve Bir Uygulama”, Atatürk Üniversitesi İktisadi ve İdari Bilimler Fakültesi Dergisi, S.1(21), ss.119-135.

KARACAOĞLU, Korhan ve YÖRÜK, Derya (2012), "Çalışanların Nepotizm ve Örgütsel Adalet Algılamaları: Orta Anadolu Bölgesinde Bir Aile İşletmesi Uygulaması", İş, Güç, Endüstri İlişkileri ve İnsan Kaynakları Dergisi, S.14(3), ss.43-64. 
KARAHAN, Atilla ve YILMAZ, Hüseyin (2014), "Nepotizm ve Örgütsel Bağlllık Arasındaki İlişkinin İncelenmesi ve Bir Uygulama", Selçuk Üniversitesi Sosyal ve Ekonomik Araştırmalar Dergisi, S.14(27), ss.124-148.

KAYA, Muammer ve ÇETIN, Ergün (2008), "Türkiye'de Araştırma-Geliştirme: Ne Durumdayız? Ne Yapmalıyzz?”, Üniversite Sanayi İşbirliği Ulusal Kongresi Bildiriler Kitabı, 26-27 Haziran 2008, Çukurova Üniversitesi Üsam Yayını, Adana.

NAKTIYOK, Atılhan (2001), “Örgüt Kültürü ve Örgüt Stratejisi Arasindaki Döngüsel İlişki”, Gaziantep Üniversitesi, Sosyal Bilimler Enstitüsü Sosyal Bilimler Dergisi, S.4(1), ss.159169.

OMBANDO, Paul Olendo (2018), "Nepotism And Job Performance in The Private And Public Organizations in Kenya", International Journal of Scientific And Research Publications, S.8(5), ss.474-494.

ÖZKANAN, Arzu ve ERDEM, Ramazan (2015), "Yönetimde Kayırmacı Uygulamalar Üzerine Nitel Bir Çalışma", Mehmet Akif Ersoy Üniversitesi İktisadi ve İdari Bilimler Fakültesi Dergisi, S.2(4), ss.728.

ÖZKAN, Çiğdem ve GÜMÜŞ, Murat (2013), "Ege Bölgesinde 4-5 Yıldızlı Otel İşletmelerinde Örgüt Kültürünün İş Değerlerinin Dönüşümüne Etkileri”, Karamanoğlu Mehmetbey Üniversitesi Sosyal ve Ekonomik Araştırmalar Dergisi, S.15(25), ss. 1-14.

ÖZLER, Hayrettin, ÖZLER, Derya Ergun ve GÜMÜŞTEKİN, Gülten Eren, (2007), "Aile İşletmelerinde Nepotizmin Gelişim Evreleri ve Kurumsallaşma", Selçuk Üniversitesi Sosyal Bilimler Enstitüsü Dergisi, S.17, ss.437-450.

ÖZLER, Derya Ergun ve BÜYÜKARSLAN, Alper (2011), "The Overall Outlook of Favoritism in Organizations : A Literatüre Review", International Journal of Business and Management Studies, S.3(1), ss.275-285.

ÖZSEMERCI, Kemal (2002), Türk Kamu Yönetiminde Yolsuzluklar: Nedenleri, Zararları ve Çözüm Önerileri, Sayıştay Yayını, Ankara.

PEARCE, Jone L. (2015), “Cronyism and Nepotism Are Bad for Everyone: The Research Evidence", Industrial and Organizational Physchology, S.8(1), ss.41-44.

ROBINS, Stephan P. ve COULTER, Mary (2007), Management, Prentice Hall, U.S.A to United Kingdom, Ninth Edition.

SUNDELL, Anders (2013), Nepotism in the Swedish Central Public Administration 1790-1925, APSA 2013 Annual Meeting Report.

TÜIK - TÜRKIYE İSTATISTIK KURUMU (2018), Uluslararası Göç İstatistikleri 2017, Tüik Yayını, Ankara, http://tuik.gov.tr/PreHaberBultenleri.do?id=30607= (Erişim Tarihi: 30.05.2019).

UZ, Abdullah (2011), “Anayasal Bir Hak Olarak Kamu Hizmetine Girme Hakkı ve Liyakat Ilkesi”, İnönü Üniversitesi Hukuk Fakültesi Dergisi, S.1(2), ss.59-94.

ZHAOJiE, Cao ve ROGER, B. Hill (2019), "Work Ethic in China Changes Over Time From 2004 to 2018", International Journal of Vocational Educartion and Training Research, S.5(1), ss.10-15. 